\begin{tabular}{|c|c|c|}
\hline & Int.J.Curr.Microbiol.App.Sci (2021) 10(10): 470-480 & \\
\hline EXCELLENT & $\begin{array}{l}\text { International Journal of Current Microbiology and Applied Sciences } \\
\text { ISSN: 2319-7706 Volume } 10 \text { Number } \mathbf{1 0}(\mathbf{2 0 2 1 )} \\
\text { Journal homepage: } \underline{\text { http://www.ijcmas.com }}\end{array}$ & $\$$ \\
\hline $\begin{array}{l}\text { EXCELLENT } \\
\text { PUBLISHERS }\end{array}$ & & www.ijcmas.com \\
\hline
\end{tabular}

\title{
Understanding Nature and Magnitude of Gene Action Under Influence of Different Dates of Sowing for Yield and Oil Content in Brassica juncea L.
}

\author{
Aditi Eliza Tirkey*, Kartikeya Srivastava, Girish Tantuway and Omesh Kumar \\ Department of Genetics and Plant Breeding, Institute of Agricultural Sciences, \\ Banaras Hindu University, Varanasi-221005, India \\ *Corresponding author
}

\section{A B S T R A C T}

\section{Keywords}

Gene action,

Generation mean

analysis,

Quantitative traits, Indian mustard,

Seed yield,

Epistasis.

\section{Article Info}

Accepted: 18 September 2021 Available Online: 10 October 2021
Ongoing research suggests that the average global temperature on Earth has increased by a little more than $1^{\circ}$ Celsius so, it is important to study effect of abiotic stresses, on plant growth since change in environment causes change in behaviour or mode of expression of genes in a genetic population and limits plants in achieving their potential yield. Keeping these points in mind the adequacy of different genetic models and nature and magnitude of gene effects responsible for the expression of seed yield and important yield contributing characters were studied in mustard. Six generations of three crosses viz; Kranti $\times$ PM 25, Vardan $\times$ PM 25 and NRCHB $101 \times$ PM 25 sown in Compact Family Block Design in timely and late sown conditions were investigated. The characters Seed yield per plant (g) and Oil content (\%) were studied. Findings suggested that different characters in the same cross or same character in different crosses in different sowing conditions showed different type and magnitude of gene effects. Data recorded suggested that dominance played a major role in the inheritance of the studied traits and that the genes involved in the inheritance of these traits are predominantly dispersed in the parents with the presence of duplicate and complementary epistasis. Presence of interaction effects and duplicate epistasis suggested the possibilities of obtaining transgressive segregants in later generations. The importance of fixable and non-fixable gene action in controlling different yield and component traits was also observed. The present findings helped in deciding effective selection methods and breeding strategies to get desired improvement in seed yield and related traits for heat stress.

\section{Introduction}

Recently a shifts in the use of oilseeds for fuel have caused changes in food oil consumption patterns. This has increased the demand of oilseed in different industries owing to the increase in usage for different purposes of oil, meal and condiments. Among the seven edible oilseeds cultivated in India, rapeseed-mustard (Brassica spp.) contributes $28.6 \%$ in the total production of oilseeds. In India Oilseeds occupies an area of 24.65 million hectares and 
produces approximately 31.31 million tonnes with average productivity of $1270 \mathrm{~kg} / \mathrm{ha}$ under this rapeseed mustard occupies an area of 5.96 million hectares and produce around 8.32 million tonnes with productivity of $1397 \mathrm{~kg} / \mathrm{ha}$ (Directorate of Economics and Statistics, DAC\&FW, 2018). According to an ongoing temperature analysis conducted by scientists at NASA's Goddard Institute for Space Studies (GISS), the average global temperature on Earth has increased by a little more than $1^{\circ}$ Celsius ( $2^{\circ}$ Fahrenheit) since 1880 and twothirds of the warming has occurred since 1975 , at a rate of roughly $0.15-0.20^{\circ} \mathrm{C}$ per decade. So, in this era of of fast changing climate where heat, drought, cold, and salinity are the major abiotic stresses, achieving potential yield by growing varieties that are bred for normal conditions, is difficult since different stresses adversely affects plant growth at different stages. This is because change in environment causes change in behaviour or mode of expression of genes in a genetic population. Since delayed sowing exposes crop to heat stress at terminal growth stage which is very common in the Varanasi and other adjoining districts of Uttar Pradesh.

Since seed yield is a polygenic character which is highly influenced by environment and depends on various component traits such as branches/plant, seeds/siliqua, siliqua length, main raceme length and 1000-seed weight (Manjunath et al., 2017).For breeding high yielding varieties of crop plants, breeders usually face problem of selection of desirable parents which is based on per seperformance, but many times high yielding genotype may/may not transmit its superiority to progeny. Hence, critical choice of parents is of utmost importance, particularly for improvement of complex quantitative characters such as yield. In order to select parents suitable for use in breeding programme with an aim to develop heat stress tolerant genotypes, gene action for important yield attributing traits need to be investigated. Since gene act in response to a particular environment and they have an effect on mean phenotypic performance of a metric trait. When more than one gene is governing the phenotypic expression, gene effects could be of three types additive effect, dominance deviation and epistatic effect.So, partitioning of genetic variance into its all the probable components i.e., additive, dominance and all types of epistasis which can be detected by generation mean analysis using the scale test, which measures epistasis accurately whether it is complimentary (AdditivexAdditive) or duplicate (AdditivexDominance) and (Dominancex Dominance) at the digenic level is vital since the commonly used mating designs diallel and Line $\times$ Tester; provide estimates of only additive and dominance/ non-additive components of gene effect in relation to whole population studied. Keeping these points in mind the present study was undertaken to understand the influence of heat stress on gene effects involved in inheritance of various quantitative and qualitative traits in Indian mustard to provide a basis for an evaluation of selection methods for the improvement of population.

\section{Materials and Methods}

\section{Plant material and experimental design}

The experimental material comprised of four contrasting parents i.e., Kranti, Vardan, NRCHB 101 and PM 25 which were selected on the basis of their geographic origin and wide variation in morphological characters and available literature. Genotypes such as Pusa Mustard 25 or NPJ-112 is reported to be heat tolerant at seedling stage, while high yielders like NRCHB -101 is Suitable for late sown irrigated condition. On the other hand, Vardan is considered as a national check in late sown condition and Kranti is national check in timely sown condition. The 
experiment involved the six basic generations (the $\mathrm{P}_{1}$ and $\mathrm{P}_{2}$ parent cultivars, the $\mathrm{F}_{1}$ and $\mathrm{F}_{2}$ first and second devoted generations, and the $\mathrm{B}_{1}$ and $\mathrm{B}_{2}$ first and second back crosses) of three cross combinations of the parental cultivars, these combinations being Kranti $\times$ PM 25, Vardan $\times$ PM 25 and NRCHB $101 \times$ PM 25 which were developed during Rabi, 2016-17 and were advanced in off-season at Wellington. The segregating and nonsegregating parental populations were cultivated in a compact block family design with three replications during the Rabi 201819 in timely and late sown condition at the Agriculture Research Farm, Institute of Agricultural Sciences, Banaras Hindu University, Varanasi.

The parents of the respective crosses used as the male parent and the $F_{1}$ generation as the female parent and effected back crosses produced the $\mathrm{B}_{1}\left(\mathrm{~F}_{1}\right.$ back crossed to $\left.\mathrm{P}_{1}\right)$ and $\mathrm{B}_{2}$ $\left(F_{1}\right.$ back crossed to $P_{2}$ ) generations and the $F_{1}$ hybrids were selfed to obtain $\mathrm{F}_{2}$ seeds. All these generations were produced during two cropping seasons and, as such, all the six generations were grown together during the same cropping season. The row-length was always three meters with a spacing $45 \times 15 \mathrm{~cm}$, but the number of rows varied as follows one row for the non-segregating $\mathrm{P}_{1}, \mathrm{P}_{2}$ and $\mathrm{F}_{1} ; 5$ rows, for segregating the $\mathrm{F}_{2}$; and three rows for the $B_{1}$ and $B 2$ generations. Number of plants analysed varied as follows: five plants in each $\mathrm{P}_{1}, \mathrm{P}_{2}$ and $\mathrm{F}_{1}$, ten plants in each $\mathrm{B}_{1}$ and $\mathrm{B}_{2}$ and fifteen plants in $\mathrm{F}_{2}$ from each replication. Seed yield per plant (g) Oil content $(\%)$ were studied.

\section{Statistical and biometrical analysis}

For both the characters under study, means of all six generations $\left(\mathrm{P}_{1}, \mathrm{P}_{2}, \mathrm{~F}_{1}, \mathrm{~F}_{2}, \mathrm{~B}_{1}\right.$ and $\left.\mathrm{B}_{2}\right)$ of each three families viz.; Kranti $\times$ PM 25, Vardan $\times$ PM 25 and NRCHB $101 \times$ PM 25in timely and late sown conditions were first subjected to regular analysis of variance was firstly performed for testing the significance of six populations within each cross for all the studied traits (Gomez and Gomez, 1984). The A, B, C and D scaling tests as outlined by Mather (1949) and Hayman and Mather (1955) were then applied to test the presence of non-allelic interactions. Joint scaling test proposed by Cavalli (1952) as indicated by " $\chi 2$ " was applied for testing the goodness of fit of the adequate genetic model controlling the studied traits. Simple genetic model $\{\mathrm{m}, \mathrm{d}$ and h) was applied when epistasis was absent. Whereas, in the presence of non-allelic interaction, the analysis was proceeded to compute the interaction types involved using the six parameters genetic model according to Jinks and Jones (1958) to gain understanding on mode of gene action. The extent of heterosis was expressed as the percentage increase of $\mathrm{F}_{1}$ above mid-parents. Inbreeding depression was calculated as the difference between the $F_{1}$ and $F_{2}$ means expressed as a percentage of the $F_{1}$ mean. The T-test was used to determine the significance of these deviations. The Potency Ratio (PR) was computed from generation means as per Peter and Frey (1966) to determine the degree of dominance. Based on the potency ratio, the degree of dominance in respect of different traits, were classified as follows: Complete dominance was indicated when Potence ratio $=+1$, Partial dominance is indicated when Potence ratio is between -1 and +1 , Overdominances indicated when potency ratio exceeds \pm 1 . Absence of dominance is indicated when Potence ratio $=0$. The positive and negative signs indicate the direction of dominance of either parent.

\section{Results and Discussion}

\section{Analysis of variance}

The results indicated the presence of significant differences among crosses for all 
studied traits. Also, the results revealed that the populations within each cross exhibited significant differences for the three crosses studied in both the conditions. This significant variation suggested the existence of some sort of genetic variability between the used parental lines which is a prerequisite to perform generation mean analysis to study inheritance of the targeted traits and the variability might manifest their difference in their genetic background.

\section{Mean performance}

The six population means and their standard error of studied crosses for all traits were calculated and the obtained results are shown in Table 1. There are highly significant differences between parental Indian mustard in the three crosses for all studied traits at both conditions. Seed yield per plant (g) and Oil content $(\%)$ in both timely and late sown conditions would be desirable for getting high yielding plants even in heat stress. Vardan recorded highest mean for yield per plant $(13.11 \mathrm{~g})$ in late sown condition in cross combination with PM 25. Similarly, PM 25 recorded highest mean for oil content (42.01) in timely sown condition in cross combination with Vardan. $\mathrm{BC}_{1}$ recorded highest mean for yield per plant in cross Vardan $\times$ PM 25 $(17.79 \mathrm{~g})$ in timely sown condition and cross Kranti $\times$ PM 25 (13.5) in late sown condition and for oil content in all the three crosses in late sown condition. $\mathrm{BC}_{2}$ recorded highest mean for yield per plant in cross Kranti $\times$ PM 25 (34.78) in timely sown condition; for oil content in cross NRCHB $101 \times$ PM 25 (42.75) in timely sown condition. In timely sown condition Vardan as $\mathrm{P}_{1}$ had greater mean value than its $F_{1}($ Vardan $\times$ PM 25) for yield per plant. While $\mathrm{P}_{2}$ (PM 25) had higher per se performance than its respective $F_{1}$, for oil content $\left(\right.$ Kranti $\times$ PM 25). $\mathrm{BC}_{1}$ was greater than $\mathrm{BC}_{2}$ in cross Vardan $\times \mathrm{PM} 25$ for yield per plant and oil content; $\mathrm{BC}_{2}$ recorded higher mean than $\mathrm{BC}_{1}$ in cross Kranti $\times$ PM 25 for yield per plant and oil content and in cross NRCHB101 $\times$ PM 25 for yield per plant and oil content. In late sown condition, Kranti as $\mathrm{P}_{1}$ had lower mean value than its $\mathrm{F}_{1}$ (Kranti $\times$ PM 25) for both the traits considered while Vardan as $\mathrm{P}_{1}$ had greater mean value than its $F_{1}$ (Vardan $\times$ PM 25) for yield per plant and oil content. While $\mathrm{P}_{2}$ (PM 25) had higher per se performance than its respective $\mathrm{F}_{1}$ for yield per plant (Vardan $\times$ PM 25). $F_{2}$ was Greater than $F_{1}$ in Vardan $\times$ PM 25 for seed yield per plant in late sown condition and oil content in both timely and late sown condition. In the remaining cases $F_{1}$ was greater than $F_{2}$. The results showed that the $F_{2}$ generations appeared to be superior over their $F_{1}$ hybrids. These findings reflected the presence of transgressive segregation and/or epistasis which indicated to the role of additive and epistasis gene effects in the inheritance of these traits with respect to the previous crosses. In cases where $F_{1}$ was greater than $F_{2}$ presence of heterotic effect and non-additive genetic variance plays the major role in the inheritance of these traits. For traits where $\mathrm{F}_{2}$ greater than $\mathrm{F}_{1}, \mathrm{BC}_{1}$ and $\mathrm{BC}_{2}$ suggests that mean values of the generated population fall outside the parental range for these traits and implying role of dominance and over dominance gene expression.

$\mathrm{BC}_{1}$ was greater than $\mathrm{BC}_{2}$ in cross Vardan $\times$ PM 25 for yield per plant and oil content; and in cross NRCHB $101 \times$ PM 25 for oil content. $\mathrm{BC}_{2}$ recorded higher mean than $\mathrm{BC}_{1}$ in cross NRCHB101 × PM 25 for yield per plant. Influence of Kranti was more than PM 25 for yield per plant in late sown condition; while Vardan had greater influence than PM 25 for yield per plant in both timely and late sown condition and for oil content in late sown condition. The results also revealed that the backcrosses mean of most of studied crosses tended toward the respective recurrent parents in most of studied traits preferred the role of 
additive and dominance gene action effects. The above results suggests that the crosses which involved at least one of the highest parents with respect to particular trait studied had the highest mean values for these traits.

\section{Scaling test to test adequacy of the genetic model}

To determine gene action controlling inheritance of all studied traits in the corresponding crosses at each location, the scaling test (A, B, C and D) and joint scaling test $(\chi 2)$ was used as shown in Table 2 . The A, $\mathrm{B}, \mathrm{C}$ and D scaling tests were carried out for 2 traits indicated the presence of non-allelic interactions in almost all cases.

The A and B scaling tests provided the evidence for the presence of all three types of epistasis viz., additive $\times$ additive, additive $\times$ dominance and dominance $\times$ dominance, type gene interactions. The $\mathrm{C}$ and $\mathrm{D}$ scaling tests provided a test for dominance $\times$ dominance and additive $\times$ additive type of epistasis, respectively. The results of scaling test showed that one or more of the four scales were significant or highly significant for all studied traits, except in crosses Kranti $\times$ PM 25 in timely sown condition for oil content and NRCHB $101 \times$ PM 25 in timely sown condition for seed yield per plant suggesting either gene interaction or linkage or both are playing an important role in the expression of this character. Similar findings were additive dominance model was sufficient to explain the gene action in crosses was reported by Habiba, et al., 2016. These results were confirmed by highly significant joint scaling test $\left(\chi^{2}\right)$. Significant values for all scaling tests indicated the presence of non-allelic interactions, hence six parameter model was used to explain the nature of gene action and types of epistasis where complex genetic model was found to be controlling the inheritance of these traits (Table 2).

\section{Gene action}

\section{Three-parameter model}

For non-interacting crosses three- parameter model is used for estimation of genetic components i.e., when epistasis is insignificant the main effects $(d, h)$ account for the total phenotypic mean performance of a cross. For yield per plant, $m$ and $h$ gene effects were found significant in cross NRCHB $101 \times$ PM 25 at timely sown condition. For oil content, $m$ and $h$ gene effects were found significant in cross Kranti $\times$ PM 25 at timely sown condition.

Six-parameter model to understand gene action and epistasis effects for traits considered for this study

\section{Yield per plant}

All the crosses at timely and late sown conditions showed significance for $m$ (mean) gene effects. Kranti $\times$ PM 25 at timely sown condition showed significance for $h, i, \mathrm{j}$ and $l$ gene effects. Cross Vardan $\times$ PM 25 at timely sown condition showed significance for $d, h, i$ and $l$ gene effects for Yield per plant. In cross Kranti $\times$ PM 25 at timely sown condition $l$ (dominance $\times$ dominance) gene effect was found significant. $d$ and $l$ were found to be significant in cross NRCHB101 $\times$ PM 25 at late sown condition. Interaction gene effects (i, $j$ and 1) was found to be higher than the main gene effect $(d, h)$ in crosses NRCHB 101 $\times$ PM 25 at late sown condition.

Remaining crosses exhibited high value of main gene effect $(d, h)$. Among interaction gene effects $i$ (additive $\times$ additive interaction) was found to be higher in crosses Kranti $\times$ PM 25 and Vardan $\times$ PM 25, at timely and late sown condition whereas in cross NRCHB101 $\times$ PM 25 at late sown condition dominance $\times$ dominance $(l)$ was higher. High value of $h$ 
(dominance effect) was observed in all the crosses in both the conditions suggesting that the genes are dispersed in the parents.

Duplicate type epistasis was observed in crosses Kranti $\times$ PM 25 and VARDAN $\times$ PM 25 , at timely sown condition this limits the variability range thus selection can be delayed to advanced generation to benefit from the decrease of non-fixable genetic variation and to exploit transgressive segregation due to significant additive $\times$ additive gene effects and duplicate type of epistasis.

\section{Oil content}

All the crosses at timely and late sown conditions except Kranti $\times$ PM 25 at timely sown condition showed significance for $m$ (mean) gene effects. Vardan $\times$ PM 25 at timely sown condition showed significance for $h, i, j$ and $l$ gene effects. In cross NRCHB 101 $\times$ PM 25 at timely sown condition $d$ (additive) and $l$ (dominance $\times$ dominance) gene effects were found significant on the other hand at late sown condition cross NRCHB101 $\times$ PM 25 showed significance for all the gene effects except for $l$ (dominance $\times$ dominance).

In Kranti $\times$ PM 25 at late sown condition $h, i$ and $\mathrm{j}$ gene effects were significant. Interaction gene effects $(i, j$ and $l$ ) was found to be higher than the main gene effect $(d, h)$ in all the crosses at timely sown condition while all the crosses at late sown condition exhibited high value of main gene effect $(d, h)$. Among interaction gene effects, cross Vardan $\times \mathrm{PM}$ 25 at timely sown condition and Kranti $\times$ PM 25 and NRCHB101 $\times$ PM 25 at late sown condition showed higher $j$ (additive $\times$ dominance interaction).

In crosses Kranti $\times$ PM 25 at timely sown condition $l$ (dominance $\times$ dominance) was found to be higher. High $i$ (additive $\times$ additive) was seen in crosses NRCHB101 $\times$
PM 25 at timely sown condition and Vardan $\times$ PM 25 at late sown condition. High value of $d$ (additive effect) was observed among the main gene effects $(d$ and $h)$ in crosses Vardan $\times$ PM 25 at timely and late sown condition and NRCHB101 $\times$ PM 25 at late sown condition. Duplicate type epistasis was observed in crosses Kranti $\times$ PM 25 at late sown condition, Vardan $\times$ PM 25 at timely sown condition and NRCHB101 $\times$ PM 25 at late sown condition.

Duplicate type of nonallelic gene interaction further confirms the prevalence of dominance effects (Singh and Sharma 2001). These results were in agreement with Cheema and Sadaqat (2004) reported that additive and nonadditive type of gene action controlling its expression for oil content. Also, Kant and Gulati (2001) reported different parameters across different crosses and environments. Duplicate-type epistasis in most of the cases indicated predominantly dispersed alleles at the interacting loci. Duplicate epistasis for different traits had also been reported by, and Singh et al., (2012) they also reported the presence of duplicate epistasis for seed yield and oil content. Dominance gene effects were found to be relatively more important, as indicated by the fact that in all cases the dominance effect $[\mathrm{h}]$ value was much higher than the additive values [d].In a study related to Brassica species, Habiba, et al., 2016, Cheema and Sadaqat (2004) reported that additive and non-additive type of gene action controlling its expression for oil content.

Kant and Gulati (2001) reported significance of different parameters across different crosses and environments. Cheema and Sadaqat (2004) also reported about the role of change in environment effects different traits contributing to yield components. Khuble et al., (1998) revealed that both additive and non-additive gene effects played major role in controlling the expression of various traits in B. juncea. 
Table.1 Mean performance of six populations for different traits in the three Indian mustard crosses for all studied traits in timely and late sown condition during 2018-19 season

\begin{tabular}{|c|c|c|c|c|c|c|c|c|c|c|c|c|c|c|c|c|c|c|c|}
\hline \multirow[t]{2}{*}{ Cross } & Condition & \multicolumn{3}{|c|}{ P1 } & \multicolumn{3}{|c|}{$\mathbf{P 2}$} & \multicolumn{3}{|c|}{ F1 } & \multicolumn{3}{|c|}{ F2 } & \multicolumn{3}{|c|}{ BC1 } & \multicolumn{3}{|c|}{ BC2 } \\
\hline & $\begin{array}{l}\text { Sample } \\
\text { Size }\end{array}$ & \multicolumn{3}{|c|}{5} & \multicolumn{3}{|c|}{5} & \multicolumn{3}{|c|}{5} & \multicolumn{3}{|c|}{15} & \multicolumn{3}{|c|}{10} & \multicolumn{3}{|c|}{10} \\
\hline \multicolumn{20}{|c|}{ YIELD PER PLANT } \\
\hline $\begin{array}{l}\text { KRANTI } \\
\text { X PM } 25\end{array}$ & IMELY & $\begin{array}{c}12.6 \\
5\end{array}$ & \pm & $\begin{array}{c}0.68 \\
9\end{array}$ & $\begin{array}{c}11.3 \\
8\end{array}$ & \pm & $\begin{array}{c}0.58 \\
7\end{array}$ & $\begin{array}{c}15.3 \\
1\end{array}$ & \pm & $\begin{array}{c}0.26 \\
5\end{array}$ & $\begin{array}{c}12.6 \\
5\end{array}$ & \pm & $\begin{array}{c}1.07 \\
1\end{array}$ & $\begin{array}{c}17.5 \\
0\end{array}$ & \pm & $\begin{array}{c}1.21 \\
3\end{array}$ & $\begin{array}{c}18.2 \\
4\end{array}$ & \pm & $\begin{array}{c}1.47 \\
7\end{array}$ \\
\hline $\begin{array}{l}\text { VARDAN } \\
\text { X PM } 25\end{array}$ & & $\begin{array}{c}13.6 \\
2\end{array}$ & \pm & $\begin{array}{c}1.35 \\
8\end{array}$ & $\begin{array}{c}11.3 \\
8\end{array}$ & \pm & $\begin{array}{c}0.58 \\
7\end{array}$ & $\begin{array}{c}12.9 \\
1\end{array}$ & \pm & $\begin{array}{c}1.30 \\
1\end{array}$ & $\begin{array}{c}12.6 \\
0\end{array}$ & \pm & 1.22 & $\begin{array}{c}17.7 \\
9\end{array}$ & \pm & $\begin{array}{c}1.80 \\
9\end{array}$ & $\begin{array}{c}15.0 \\
1\end{array}$ & \pm & $\begin{array}{c}1.19 \\
8\end{array}$ \\
\hline $\begin{array}{l}\text { NRCHB10 } \\
1 \text { X PM } 25\end{array}$ & & 9.42 & \pm & $\begin{array}{c}0.63 \\
6\end{array}$ & $\begin{array}{c}12.6 \\
5\end{array}$ & \pm & 1.32 & $\begin{array}{c}14.5 \\
1\end{array}$ & \pm & 0.84 & $\begin{array}{c}13.7 \\
1\end{array}$ & \pm & $\begin{array}{c}1.35 \\
5\end{array}$ & $\begin{array}{c}12.4 \\
2\end{array}$ & \pm & $\begin{array}{c}1.31 \\
9\end{array}$ & $\begin{array}{c}13.3 \\
6\end{array}$ & \pm & $\begin{array}{c}1.60 \\
3\end{array}$ \\
\hline $\begin{array}{l}\text { KRANTI } \\
\text { X PM } 25\end{array}$ & LATE & $\begin{array}{c}10.9 \\
8\end{array}$ & \pm & $\begin{array}{c}1.46 \\
3\end{array}$ & $\begin{array}{c}10.3 \\
9\end{array}$ & \pm & 2.44 & $\begin{array}{c}12.7 \\
4\end{array}$ & \pm & $\begin{array}{c}2.48 \\
7\end{array}$ & 9.87 & \pm & $\begin{array}{c}1.23 \\
1\end{array}$ & $\begin{array}{c}13.5 \\
0\end{array}$ & \pm & $\begin{array}{c}2.22 \\
4\end{array}$ & $\begin{array}{c}11.6 \\
3\end{array}$ & \pm & $\begin{array}{c}2.89 \\
2\end{array}$ \\
\hline $\begin{array}{l}\text { VARDAN } \\
\text { X PM } 25\end{array}$ & & $\begin{array}{c}13.1 \\
1\end{array}$ & \pm & $\begin{array}{c}1.51 \\
7\end{array}$ & $\begin{array}{c}10.9 \\
0\end{array}$ & \pm & $\begin{array}{c}1.86 \\
7\end{array}$ & 8.45 & \pm & $\begin{array}{c}1.62 \\
8\end{array}$ & 8.71 & \pm & 1.07 & $\begin{array}{c}10.7 \\
0\end{array}$ & \pm & $\begin{array}{c}1.86 \\
7\end{array}$ & 9.79 & \pm & $\begin{array}{c}1.97 \\
4\end{array}$ \\
\hline $\begin{array}{l}\text { NRCHB10 } \\
1 \text { X PM } 25\end{array}$ & & 9.58 & \pm & $\begin{array}{c}0.76 \\
5\end{array}$ & $\begin{array}{c}10.5 \\
0\end{array}$ & \pm & $\begin{array}{c}1.83 \\
6\end{array}$ & $\begin{array}{c}10.7 \\
2\end{array}$ & \pm & $\begin{array}{c}2.49 \\
1\end{array}$ & 8.88 & \pm & $\begin{array}{c}0.94 \\
6\end{array}$ & 6.24 & \pm & $\begin{array}{c}0.64 \\
8\end{array}$ & 8.69 & \pm & $\begin{array}{c}1.30 \\
9\end{array}$ \\
\hline \multicolumn{20}{|c|}{ OIL CONTENT } \\
\hline $\begin{array}{l}\text { KRANTI } \\
\text { X PM } 25\end{array}$ & TIM & $\begin{array}{c}40.3 \\
3\end{array}$ & \pm & $\begin{array}{c}0.33 \\
9\end{array}$ & $\begin{array}{c}42.0 \\
1\end{array}$ & \pm & $\begin{array}{c}0.07 \\
3\end{array}$ & $\begin{array}{c}42.7 \\
4\end{array}$ & \pm & $\begin{array}{c}0.33 \\
1\end{array}$ & $\begin{array}{c}42.2 \\
0\end{array}$ & \pm & $\begin{array}{c}0.33 \\
2\end{array}$ & $\begin{array}{c}41.7 \\
3\end{array}$ & \pm & $\begin{array}{c}0.37 \\
6\end{array}$ & $\begin{array}{c}42.0 \\
7\end{array}$ & \pm & $\begin{array}{c}0.43 \\
3\end{array}$ \\
\hline $\begin{array}{l}\text { VARDAN } \\
\text { X PM } 25\end{array}$ & & $\begin{array}{c}40.2 \\
6\end{array}$ & \pm & $\begin{array}{c}0.30 \\
3\end{array}$ & $\begin{array}{c}42.0 \\
1\end{array}$ & \pm & $\begin{array}{c}0.07 \\
3\end{array}$ & $\begin{array}{c}41.1 \\
6\end{array}$ & \pm & $\begin{array}{c}0.51 \\
2\end{array}$ & $\begin{array}{c}41.3 \\
3\end{array}$ & \pm & $\begin{array}{c}0.31 \\
1\end{array}$ & $\begin{array}{c}41.0 \\
0\end{array}$ & \pm & $\begin{array}{c}0.29 \\
4\end{array}$ & $\begin{array}{c}39.9 \\
8\end{array}$ & \pm & $\begin{array}{c}0.43 \\
5\end{array}$ \\
\hline $\begin{array}{l}\text { NRCHB10 } \\
1 \text { X PM } 25\end{array}$ & & $\begin{array}{c}42.0 \\
3\end{array}$ & \pm & $\begin{array}{c}0.15 \\
6\end{array}$ & $\begin{array}{c}42.0 \\
1\end{array}$ & \pm & $\begin{array}{c}0.07 \\
3\end{array}$ & $\begin{array}{c}41.6 \\
7\end{array}$ & \pm & $\begin{array}{c}0.35 \\
1\end{array}$ & $\begin{array}{c}42.0 \\
4\end{array}$ & \pm & $\begin{array}{c}0.19 \\
8\end{array}$ & $\begin{array}{c}41.5 \\
5\end{array}$ & \pm & $\begin{array}{c}0.07 \\
6\end{array}$ & $\begin{array}{c}42.7 \\
5\end{array}$ & \pm & $\begin{array}{c}0.10 \\
3\end{array}$ \\
\hline $\begin{array}{l}\text { KRANTI } \\
\text { X PM } 25\end{array}$ & \multirow[t]{3}{*}{ LATE } & $\begin{array}{c}35.9 \\
7\end{array}$ & \pm & $\begin{array}{c}0.22 \\
6\end{array}$ & $\begin{array}{c}38.2 \\
2\end{array}$ & \pm & $\begin{array}{c}0.13 \\
6\end{array}$ & $\begin{array}{c}41.8 \\
5\end{array}$ & \pm & $\begin{array}{c}0.71 \\
3\end{array}$ & $\begin{array}{c}39.9 \\
5\end{array}$ & \pm & $\begin{array}{c}0.72 \\
2\end{array}$ & $\begin{array}{c}41.9 \\
8\end{array}$ & \pm & $\begin{array}{c}0.30 \\
4\end{array}$ & $\begin{array}{c}41.7 \\
2\end{array}$ & \pm & $\begin{array}{c}0.10 \\
6\end{array}$ \\
\hline $\begin{array}{l}\text { VARDAN } \\
\text { X PM } 25\end{array}$ & & $\begin{array}{c}40.0 \\
6\end{array}$ & \pm & 0.19 & $\begin{array}{c}38.2 \\
7\end{array}$ & \pm & $\begin{array}{c}0.12 \\
7\end{array}$ & $\begin{array}{c}39.3 \\
7\end{array}$ & \pm & $\begin{array}{c}0.13 \\
4\end{array}$ & $\begin{array}{c}40.2 \\
2\end{array}$ & \pm & $\begin{array}{c}0.23 \\
2\end{array}$ & $\begin{array}{c}40.1 \\
9\end{array}$ & \pm & 0.45 & $\begin{array}{c}39.8 \\
5\end{array}$ & \pm & 0.41 \\
\hline $\begin{array}{l}\text { NRCHB10 } \\
1 \text { X PM } 25\end{array}$ & & $\begin{array}{c}37.6 \\
2\end{array}$ & \pm & $\begin{array}{c}0.30 \\
8\end{array}$ & $\begin{array}{c}39.2 \\
7\end{array}$ & \pm & $\begin{array}{c}0.12 \\
7\end{array}$ & $\begin{array}{c}39.3 \\
4\end{array}$ & \pm & $\begin{array}{c}0.14 \\
7\end{array}$ & $\begin{array}{c}32.7 \\
7\end{array}$ & \pm & $\begin{array}{c}1.65 \\
3\end{array}$ & $\begin{array}{c}41.3 \\
1\end{array}$ & \pm & $\begin{array}{c}0.07 \\
4\end{array}$ & $\begin{array}{c}40.3 \\
4\end{array}$ & \pm & $\begin{array}{c}0.08 \\
9\end{array}$ \\
\hline
\end{tabular}


Table.2 Scaling test (A, B, C and D) along with estimates of gene effects of the three and six-parameter genetic model in the three Indian mustard crosses for all studied traits in timely and late sown condition along with heterosis, inbreeding depression, potence ratio and number of effective genes in the year 2018-19 for yield per plant and oil content.

\begin{tabular}{|c|c|c|c|c|c|c|c|c|c|c|c|c|c|}
\hline \multirow{3}{*}{\multicolumn{2}{|c|}{$\begin{array}{c}\text { TRAITS } \\
\text { ENVIRONMENT } \\
\text { CROSS }\end{array}$}} & \multicolumn{6}{|c|}{ YIELD PER PLANT } & \multicolumn{6}{|c|}{ OIL CONTENT } \\
\hline & & \multicolumn{3}{|c|}{ TIMELY } & \multicolumn{3}{|c|}{ LATE } & \multicolumn{3}{|c|}{ TIMELY } & \multicolumn{3}{|c|}{ LATE } \\
\hline & & $\sum_{\substack{\mid c \\
\Sigma}}^{n}$ & $\sum_{j}^{Z} \times \sum_{\substack{i \\
j}}^{n}$ & 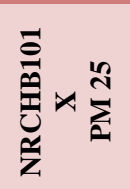 & 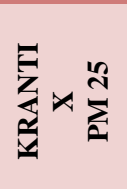 & 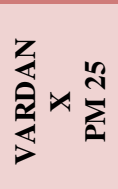 & 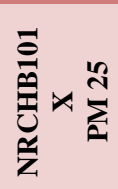 & $\sum_{\substack{\mid c \\
\Sigma}}$ & 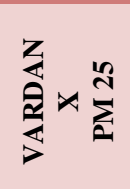 & 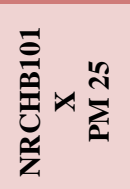 & 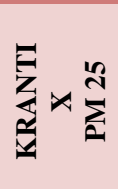 & 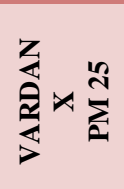 & 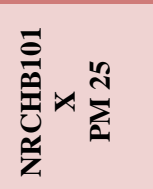 \\
\hline \multirow[t]{5}{*}{ SCALING TEST } & $\mathbf{A}$ & $-7.04 *$ & $-3.84^{*}$ & -0.55 & -0.87 & 0.07 & $4.65^{* *}$ & -0.4 & -1.19 & $2.52 *$ & $-9.01 *$ & -1.79 & $-26.38 *$ \\
\hline & B & $-9.77 * *$ & $-3.56 * *$ & 0.22 & -0.03 & -0.09 & 1.64 & 0.61 & $5.49 * *$ & $-7.61 * *$ & $-6.31 * *$ & $-4.25 * *$ & $-13.62 * *$ \\
\hline & $\mathbf{C}$ & $4.08 * *$ & 0.13 & -1.11 & 1.38 & 1.78 & 1.59 & -1 & -0.78 & -1.25 & -0.83 & $-6.62 * *$ & $6.40 * *$ \\
\hline & D & $-10.45 * *$ & $-4.03 * *$ & 0.83 & $-1.73^{*}$ & $-1.54^{*}$ & $2.05^{*}$ & 0.6 & $3.59 * *$ & $-0.93 *$ & $-3.64 * *$ & 0.88 & $-8.44 * *$ \\
\hline & $\chi^{2}$ & $58.33^{* *}$ & $26.73 * *$ & 1.59 & 4.31 & 3.87 & $26.29 * *$ & 3.49 & $41.99 * *$ & $120.48^{* *}$ & $87.47 * *$ & $60.05 * *$ & $824.98 * *$ \\
\hline \multicolumn{2}{|c|}{ EPISTASIS } & present & present & - & present & present & present & - & present & present & present & present & present \\
\hline \multicolumn{2}{|c|}{$\begin{array}{l}\text { TYPE OF NON-ALLELIC } \\
\text { INTERACTION }\end{array}$} & $i, j, 1$ & $\mathrm{j}, \mathrm{i}$ & - & i & i & $\mathrm{j}, \mathrm{i}$ & - & $\mathrm{j}, \mathrm{i}$ & $\mathrm{j}, \mathrm{i}$ & $\mathrm{j}, \mathrm{i}$ & $\mathrm{j}, 1$ & $\mathrm{i}, \mathrm{j}, \mathrm{l}$ \\
\hline \multirow{6}{*}{$\begin{array}{c}\text { SIX PARAMETER } \\
\text { MODEL }\end{array}$} & $\mathbf{m}$ & $12.65^{* *}$ & $17.89 * *$ & - & $11.34 * *$ & $14.10 * *$ & $16.26^{* *}$ & - & $229.97 * *$ & $368.08 * *$ & $78.25 * *$ & $299.74 * *$ & $34.33 * *$ \\
\hline & d & -0.73 & $2.21 *$ & - & 0.73 & 0.57 & $-2.90 * *$ & - & $3.36 * *$ & $-16.24 * *$ & 1.13 & 0.97 & $14.52 * *$ \\
\hline & h & $24.19 * *$ & $4.04 * *$ & - & 1.96 & 0.62 & -1.57 & - & $-3.38 * *$ & 0.18 & $5.74 * *$ & -0.65 & $8.66^{* *}$ \\
\hline & i & $20.90 * *$ & $4.03 * *$ & - & 1.73 & 1.54 & $-2.05^{*}$ & - & $-3.59 * *$ & 0.93 & $3.64 * *$ & -0.88 & $8.44 * *$ \\
\hline & $\mathbf{j}$ & $-2.73 * *$ & 1.25 & - & 0.57 & -0.12 & -1.95 & - & $5.98 * *$ & $-13.58 * *$ & $5.63 * *$ & -1.54 & $15.33 * *$ \\
\hline & 1 & $-37.72 *$ & $-5.00 *$ & - & -1.22 & -0.87 & $3.41 * *$ & - & $3.90 * *$ & -2.43 & -6.96 & -1.48 & -10.42 \\
\hline \multirow{3}{*}{$\begin{array}{l}\text { THREE } \\
\text { PARAMETER } \\
\text { MODEL }\end{array}$} & m & & & $14.34 * *$ & & & & $42.38 * *$ & & & & & \\
\hline & d & & & -1.62 & & & & -0.84 & & & & & \\
\hline & h & & & $30.43^{* *}$ & & & & $122.45^{* *}$ & & & & & \\
\hline \multicolumn{2}{|c|}{ TYPE OF EPISTASIS } & $\mathrm{D}$ & $\mathrm{D}$ & - & - & - & - & - & $\mathrm{D}$ & - & $\mathrm{D}$ & - & $\mathrm{D}$ \\
\hline \multicolumn{2}{|c|}{ HETEROSIS EFFECT } & $-8.11 * *$ & $17.56^{* *}$ & 0.66 & $-7.55 * *$ & 0.98 & $9.14 * *$ & 0.91 & -1.73 & 0.02 & $-2.61 * *$ & 1.13 & $-24.41 * *$ \\
\hline \multicolumn{2}{|c|}{ HETEROSIS } & 2.66 & 1.52 & 1.86 & 1.76 & -2.45 & 0.23 & 0.73 & -0.85 & -0.34 & 3.63 & 1.09 & 0.06 \\
\hline \multicolumn{2}{|c|}{ INBREEDING DEPRESSION } & 2.67 & 0.31 & 0.8 & 2.87 & -0.26 & 1.84 & 0.54 & -0.17 & -0.37 & 1.91 & -0.85 & 6.57 \\
\hline \multicolumn{2}{|c|}{ INBREEDING DEPRESSION \% } & 17.42 & 2.38 & 5.5 & 22.52 & -3.13 & 17.19 & 1.26 & -0.42 & -0.89 & 4.55 & -2.16 & 16.7 \\
\hline \multirow{3}{*}{$\begin{array}{c}\text { POTENCE } \\
\text { RATIO/LEVEL } \\
\text { OF DOMINANCE }\end{array}$} & $\begin{array}{l}\text { POTENCE } \\
\text { RATIO (h1) }\end{array}$ & 5.2 & 0.36 & -2.15 & 6.92 & -3.21 & -1.49 & -1.87 & -0.03 & -36.23 & -4.22 & 0.23 & -1.08 \\
\hline & $\begin{array}{l}\text { POTENCE } \\
\text { RATIO (h2) }\end{array}$ & 1.98 & 0.18 & -3.31 & -5.49 & -5.95 & 5.08 & -2.47 & -0.45 & 3.84 & -5.06 & 2.36 & 13.77 \\
\hline & $\begin{array}{c}\text { CASTLE- } \\
\text { WRIGHT } \\
\text { FORMULA }\end{array}$ & 0.01 & 0.05 & 0.05 & -0.01 & 0.16 & -0.01 & 0.32 & 2.65 & 0 & 0.12 & 0.55 & 0.01 \\
\hline
\end{tabular}




\section{Heterosis}

To draw the valid conclusion respecting the magnitude of heterosis relative to the better parents (heterobeltiosis), inbreeding depression percentage, potency ratio ( $\hat{\mathrm{h}} 1)$ for $\mathrm{F}_{1}$ and (h2) for $\mathrm{F}_{2}$, for all studied traits in the corresponding cross in both timely and late sown conditions were estimated as shown in Table (2). Significant positive heterosis for seed yield per plant was observed in Vardan $x$ PM 25 and NRCHB101 $\times$ PM 25 in both timely and late sown condition and for oil content Kranti $\times$ PM 25 and NRCHB101 $\times$ PM 25 in timely sown condition and Vardan $x$ PM 25 in late sown condition exhibited desirable heterosis. Low heterosis values for most of the traits may be due to narrow genetic base of parents used for the present investigation.

\section{Potence ratio}

Potence ratio of the corresponding crosses in the $F_{1}$ and $F_{2}$ generations at both locations as shown in Table (2), the results revealed that in $F_{1}$ over over dominance was seen in Kranti $x$ PM 25 for yield per plant in timely sown condition and late sown condition; Similarly, in $F_{2}$ potence ratio was found to manifest over dominance in KRANTI $\times$ PM 25 for yield per plant in timely sown condition; in cross VARDAN $\times$ PM 25 for oil content in late sown condition; in cross NRCHB101 $\times$ PM 25 for oil content in timely sown condition and yield per plant and oil content in late sown condition implying that there is preponderance of non-additive gene action and selection should be delayed to later generations for such traits. Partial dominance was revealed in cross in cross Vardan $\times$ PM 25 for yield per plant and oil content in timely sown condition. Over-dominance towards the better (desirable) parent as revealed by potence ratio was detected for both the studied traits. These results are similar to the findings obtained by
Elnenny and Shafei Wafaa (2017), Bocianowski et al., (2019), Philanim et al., (2019) and Abdelsatar et al., (2020) in canola.

Types of gene action can be employed to decide the expression for exploiting various characters under study. Different characters in the same cross or same character in different crosses in different sowing conditions show different type and magnitude of gene effects which is necessary for handling of individual cross in segregating populations. Results of the present investigation indicated that gene main (m) effects, derived from the sixparameter model, was significant for all studied traits; while significance of additive (d), dominance (h), additivexadditive (i), additivexdominance (j) and dominancex dominance (l) gene effects and allelic interactions varied among traits. All the traits in all the three crosses in both timely and late sown condition had positive and significant mean values $(m)$ suggesting dominance in positive direction i.e., in the direction of increased trait value which suggested that dominant alleles control high values of the trait. Results from present investigation also suggests that dominance played a major role in the inheritance of the studied traits in both timely and late sown conditions. This implies that the genes involved in the inheritance of these traits are predominantly dispersed in the parents. Presence of duplicate epistasis yield per plant in timely sown condition and oil content in late sown condition in cross Kranti $\times$ PM 25; for yield per plant and oil content in timely sown condition in cross Vardan $\times$ PM 25 . Over dominance, dominance and partial dominance were manifested in the studied crosses for different traits in different conditions. The magnitude of dominance and epistatic effects present in the material may be exploited through appropriate recurrent selection procedure. Based on these findings it can be concluded that the investigated traits show complex genetic behaviour, which 
suggests that early selection would be less efficient; therefore, it is recommended that delayed selection in advanced generations should be done to benefit from the decrease in non-fixable genetic variation and exploit transgressive segregators due to the significant interaction additivity xadditivity (i) of the gene and duplicated epistasis. In the present investigation, nonallelic (epistasis) interaction played significant role in determining the expression of various characters which are studied. Thus, high volume crossing like biparental and diallel selective mating systems of breeding methods takes care of additive and non-additive gene action which seems more promising for various characters for their improvement under the present investigation. Pedigree method of selection is one of the most appropriate methods of breeding for the improvement of the characters which are controlled by additive gene effect. Heterosis breeding or hybridization followed by cyclic method of breeding can exploit both additive and non-additive gene effects for improvements of different characters.

\section{Authors' contribution}

Conceptualization of research (K. Srivastava); Designing of the experiments (K. Srivastava and Aditi Eliza Tirkey); Contribution of experimental materials (DRMR and Department of Genetics and Plant breeding Institute of Agricultural Sciences); Execution of field/lab experiments and data collection (Aditi Eliza Tirkey, Girish Tantuway and Omesh Kumar); Analysis of data and interpretation (Aditi Eliza Tirkey); Preparation of the manuscript (Aditi Eliza Tirkey).

\section{References}

Abdelsatar, M. A., Mourad, Kh. A. \& Ibrahim, Suzan A. K. (2020). The genetic system controlling agronomic traits in canola. Egyptian Journal of Plant
Breeding, 24(2):349- 381. DOI: 10.12816/EJPB.2020.171007

Bocianowski, J., Nowosad, K., Dobrzycka, A., \& Wolko, J. (2019). Estimation of additive and epistatic gene effects for phenotypic and biochemical traits in double haploid lines of winter rapeseed (Brassica napus L.). Indian Journal of Genetics and Plant Breeding, 79 (3), 563-570. DOI: 10.31742/IJGPB.79.3.6

Castle, W. E., (1921). An Improved Method of Estimating the Number of Genetic Factors Concerned in Cases of Blending Inheritance. Science 54: 223. doi: 10.1126/science.54.1393.223.

Cavalli L. L. (1952). An analysis of linkage in quantitative inheritance. pp. 135-144. In: Reeve ECR and Waddington $\mathrm{CH}$ (eds). Quantitative Inheritance. HMSO, London.

Cheema, K. L. And H. A. Sadaqat (2004). Potential And Genetic Basis of Drought Tolerance in Canola (Brassica Napus): I. Generation Mean Analysis for Some Phonological and Yield Components. International Journal of Agriculture \& Biology. Vol. 6, No. 1: 74-81

Elnenny, E. M. M., \& Shafei, Wafaa W. M. (2017). Genetical analysis for seed yield and it's components in Canola. Egyptian Journal of Plant Breeding, 21 (7):1239-1250. DOI: $10.12816 / 0046594$

Gomez, K. A., \& Gomez, A. A. (1984). Statistical procedures for agricultural research. 2nd ed. New York: John Willey and Sons Inc. https://pdf.usaid.gov/pdf_docs/PNAA R208.pdf

Hayman, B. I. \& Mather K. (1955). The description of genetic interaction in continuous variation. Biometrics, 11 (1): 69-82. http://www.jstor.org/stable/3001481

Hayman, B. I. (1958). The separation of 
epistatic from additive and dominance variation in generation means. Heredity, $\quad$ 12: $\quad 371-390$. https://www.nature.com/articles/hdy 19 5836.pdf

Habiba, Rehab M. M.1; M. H. Abd El-Aziz1 and K. A. Amein (2016). Evaluation of Gene Action for Several Important Traits in Some Crosses of Canola (Brassica Napus L.) Using Generation Mean Analysis. Assiut J. Agric. Sci., (47) No. (3) $2016 \quad$ (9-23. http://www.aun.edu.eg/faculty_agricult ure/arabic

Jinks, J. L. \& Jones R. M. (1958). Estimation of the components of heterosis. Genetics, 43 (2): 223- 224. https://www.ncbi.nlm.nih.gov/pmc/arti cles/PMC1209876/pdf/223.pdf

Kant, L. and S. C. Gulati (2001). Genetic Analysis for Yield and its Components and Oil Contents in Indian Mustard (B. Juncea). Indian J. Genet., 61: 37-40. https://www.isgpb.org/documents/arch ive/ijgpb-61-1-010.pdf

Mather, K. 1949. Biometrical Genetics. The study of continuous variation. Methuen and Co. Ltd. London

Manjunath, H. Phogat, D. S. Pummy Kumari and Dhiraj Singh (2017). Genetic analysis of seed yield and yield attributes in Indian mustard (Brassica juncea (L.) Czern and Coss.). Electronic Journal of Plant Breeding, $8(1)$ : 182-186. DOI: $10.5958 / 0975-$ 928X.2017.00026.6

Philanim, W. S., U. Pant, R. Bhajan and Tondonba, S. P. (2019). Gene Action for Quantitative Traits Through Generation Mean Analysis in Indian Mustard (Brassica Juncea L.). Int.J.Curr.Microbiol.App.Sci.8(08):260 $-266$.

https://doi.org/10.20546/ijcmas.2019.8 08.031

Peter, F. C \& Frey K. J. (1966). Genotypic correlation, dominance and heritability of quantitative characters in oats, Crop Science, 6: 259-262. https://lib.dr.iastate.edu/cgi/viewconte nt.cgi? article $=3136 \&$ context $=$ rtd

\section{How to cite this article:}

Aditi Eliza Tirkey, Kartikeya Srivastava, Girish Tantuway and Omesh Kumar. 2021. Understanding Nature and Magnitude of Gene Action Under Influence of Different Dates of Sowing for Yield and Oil Content in Brassica juncea L. Int.J.Curr.Microbiol.App.Sci. 10(10): 470-480. doi: https://doi.org/10.20546/ijcmas.2021.1010.057 